\title{
Morphological Traits, Productive Performance and Genotyping Fat Deposition PPAR Gene in Gama Ayam Crossbreeds of Female $\mathrm{F}_{1}$ Kamper and Male $\mathrm{BC}_{1}$ Kambro
}

\author{
ISNA MUSTAFIATUL UMMAH ${ }^{1}$, I WAYAN SWARAUTAMA MAHARDHIKA ${ }^{1}$, BUDI \\ SETIADI DARYONO ${ }^{*}$ \\ ${ }^{1}$ Laboratory of Genetics and Breeding, Faculty of Biology, Universitas Gadjah Mada \\ Jl. Teknika Selatan, Sekip Utara, Sleman, Yogyakarta, Indonesia. 55281 \\ *Email: bs_daryono@mail.ugm.ac.id
}

Received 12 August 2019; Received in revised form 01 November 2019 Accepted 05 December 2019; Available online 30 December 2019

\begin{abstract}
On the recent classification of native Indonesian chicken there are 31 breeds of chicken. Highly circulated chicken breed in Indonesia is fast-growing broiler which include several strains such as Cobb 500, Hubbar, Hybro, Isa Hyline and Hisex. Fast-growing broiler chickens have a rapid growth, with excessive fat deposition on chicken carcass which implicates a health problem and unfavorable meat quality. Gama Ayam Research Team conducted a selective breeding which produces two new chicken breed Kamper and Kambro. A further selective breeding then crossbred female F1 Kamper and male BC1 (backcross I) Kambro. In this research morphological traits, productive performance and genotyping of PPAR gene related to fat deposition gene and blood lipid content in Gama Ayam were identified. Based on data analysis hybrid chickens morphological traits it concluded that Gama Ayam have a significant variation based on feather color. Productive performance was determined with feed-conversion ratio (FCR) value which was 3.17. Genotyping of PPAR gene resulted in four polymorphisms which formed 14 haplotypes groups. Based on blood lipid content analysis of cholesterol content, triglycerides content, HDL and LDL, Gama Ayam have significantly lower content of cholesterol (107.05 mg/dl), LDL (44.71 mg/dl) and triglycerides $(22.41 \mathrm{mg} / \mathrm{dl})$. PPAR gene polymorphisms is not correlated with blood lipid content in Gama Ayam. A significantly strong correlation between PPAR gene polymorphism on the body weight of Gama Ayam at 49-days-old. Triglyceride level, cholesterol level and LDL level in Gama Ayam were lower than broiler chicken. Further research with larger population size and sex classification of hybrid chicken must be conducted to validate the results.
\end{abstract}

Keywords: BC1 Kambro; F1 Kamper; fat deposition; Gama Ayam; selective breeding

\section{INTRODUCTION}

Over the past few decades, the main purpose of poultry production in many countries has been to improve animal growth. Ditjen PKH (2018) showed that Indonesia poultry livestock populations in 2018 consisted of 1.8 billion broiler-type/broiler chickens, 181.752 layer chickens and 310.960 native chickens. However, modern broiler strain often tend to have excessive abdominal fat deposits (Xu et al., 2003; Liang et al., 2015). Fat deposition needs to be controlled hence it has a negative impact on poultry production, as evidenced by increases in feed costs during maintenance, decreased final meat quality, and significant economic losses for the poultry processing industry (Peng et al., 2019; Wu et al., 2006; Lu et al., 2007).
Currently, excessive fat is one of the main problem faced by the poultry industry, because it's not only causes reduced carcass and feed efficiency, but also customers refusal of meat (Colmenero, 2000; wumová \& Teimouri, 2010; Wu et al., 2000). Efforts to reduce fat in chicken are one of the focuses in research on Broiler commodities (Ferrini et al., 2010). It is because consumers want healthier food products from chicken. High levels of fat in food products that come from animal are known to be a source of body obesity and coronary heart disease (Sartika, 2008; Gesta et al., 2007; Popkin, 2001). The intense genetic selection for rapid growth in broilers has resulted in an increase in voluntary feed intake and growth rate, accompanied by increased fat deposition in adipose tissue depots throughout the body 
(Wang et al., 2017). On this basis, producing chickens that contain low fat content is one of the goals sought by many poultry nutrition researchers. In the last decade, genetic mechanisms in chicken fat deposition have been widely studied to examine genotypes of genes involved in adipose regulation in chicken (Wang et al., 2008). One gene that expresses fat deposition in chickens is PPAR gene (peroxisome proliferator-activated gene receptor). This gene can mediate regulation of adipose differentiation and fat metabolism (Hattori et al., 2004; Wang et al., 2008).

Identification of native chicken germplasm resulted in 34 breeds of chicken consist of Ayunai, Balenggek, Banten, Bangkok, Burgo, Bekisar, Cangehgar, Cemani, Ciparage, Gaok, Jepun, Kampung, Kasintu, Kedu (Hitam and Putih), Pelung, Lamba, Maleo, Melayu, Merawang, Nagrak, Nunukan, Nusa Penida, Olagan, Rintit or Walik, Sedayu, Sentul, Siem, Sumatera, Tolaki, Tukung, Wareng, Sabu, and Semau (Henuk \& Bakti, 2016; Mahardhika \& Daryono, 2019). Approximately 11 native chicken breeds are categorized as candidates of broiler-type and laying-type chicken (Henuk \& Bakti, 2016; Mahardhika \& Daryono, 2019). Gama Ayam Research Team has conducted several selective breeding program with wellconstructed breeding structure which involved native chicken breed to produce meat-type and laying-type chicken breed. Gama Ayam Research Team in 2013-2014, successfully bred the F1 Kamper, a breed of chicken that inherited the characteristics of female Lohmann Brown-Classic and male Pelung. In 2018-2019 Kambro successfully bred, a breed of chicken that inherited the characteristics of female Broiler Cobb 500 and male Pelung Blirik Hitam. Based on body weight and phenotypic performance Kambro could reach approximately 1244 grams after 49-days of rearing with ad libitum diet of standard feed. Phenotypic performance of Kambro is significant to F1 Pelung based on the measurement of liner body weight parameter, vitaliity parameter, $\mathrm{PPa}-\mathrm{PBe}$ parameter and phenotype parameter (Mahardhika \& Daryono, 2019). A further selective breeding with female F1 Kamper and male BC1 Kambro was initiated to produce hybrid chicken with the combination of prominent phenotypic traits of Kamper and Kambro. Hybrid chicken later named Gama Ayam was characterized with both phenotypic performance and molecular genotyping.

\section{MATERIALS AND METHODS}

The following materials were used in this study: female $\mathrm{F}_{1}$ Kamper and male $\mathrm{BC}_{1}$ Kambro, eight Gama Ayam chicken, supplemental vitamin, BR-1 comfeed (PT. Japfa Comfeed Indonesia), AD II (PT. Japfa Comfeed Indonesia), whole blood samples, $70 \%$ alcohol, syringe $1 \mathrm{~mL}$, ethylenediaminetetraacetic acid (EDTA), pipette tips (blue, yellow, and white), chelex solution, proteinase K, 0.05 M DTT, TE buffer (IDT, Malaysia), PCR tube, microtube $1.5 \mathrm{~mL}$, agarose (BIO-1000, IDT, Malaysia), $1 \times \mathrm{TAE}$ and $0.5 \times$ florosafe DNA stain (BIO-5170, 1 st BASE, Malaysia), ddH2O, $2 \times$ MyTaq HS Red Mix (BIO-25047, 1st BASE, Malaysia), pair of primer forward primer (5'-TCT GGC TGT GTT TAC TGT GAT TG-3') and reverse primer (5'TGC ATG CAG TGT GTA TGA AAA-3') and 100-bp Bench Top Ladder (BIO-5170, 1st BASE, Malaysia). Amplicons then was sent for sequencing analysis performed according to Sanger sequencing method (PT. Genetics Science Indonesia). Blood lipid content analysis including triglyceride content, cholesterol content, LDL and HDL was analysed. Data analysis used including visual observation of phenotypic performance, body weight measurement (ANOVA), FCR calculation and sequencing analysis. FCR calculation based of formula (Parker, 2002):

$$
\text { FCR }=\frac{\text { Total feed spent at a certain time }(7 \text { weeks })}{\text { Final chicken weight at } 7 \text { weeks chicken weight beginning }}
$$




\section{RESULT AND DISCUSSION}

Based on visual observation of phenotypic traits in Table 1 Gama Ayam chicken showed a similarity in comb shape $(100 \%)$. Significant variations can be visually observed from feather color with 5 phenotypic groups: black barred
(37.5\%), white barred (25\%), black (12.5\%), white $(12.5 \%)$ and brown (12.5\%). Visual observation of phenotypic traits of Gama Ayam chicken is shown in Figure 1 with representative image of the breeding structure.

Table 1. Hybrid chicken morphology characters

\begin{tabular}{|c|c|c|c|}
\hline Phenotypic Traits & Phenotypes & Population $(n=8)$ & Percentage $(\%)$ \\
\hline Comb Shape & Single & 8 & 100 \\
\hline \multirow{2}{*}{ Comb Color } & Red & 4 & 50 \\
\hline & Reddish & 4 & 50 \\
\hline \multirow{4}{*}{ Beak Color } & Yellow & 3 & 37.5 \\
\hline & White & 3 & 37.5 \\
\hline & Blackish White & 1 & 12.5 \\
\hline & Whitish Black & 1 & 12.5 \\
\hline \multirow{3}{*}{ Shank Color } & Black & 1 & 12.5 \\
\hline & White & 6 & 75 \\
\hline & Yellow & 1 & 12.5 \\
\hline \multirow{5}{*}{ Feather Color } & Black Barred & 3 & 37.5 \\
\hline & White Barred & 2 & 25 \\
\hline & Black & 1 & 12.5 \\
\hline & White & 1 & 12.5 \\
\hline & Brown & 1 & 12.5 \\
\hline
\end{tabular}

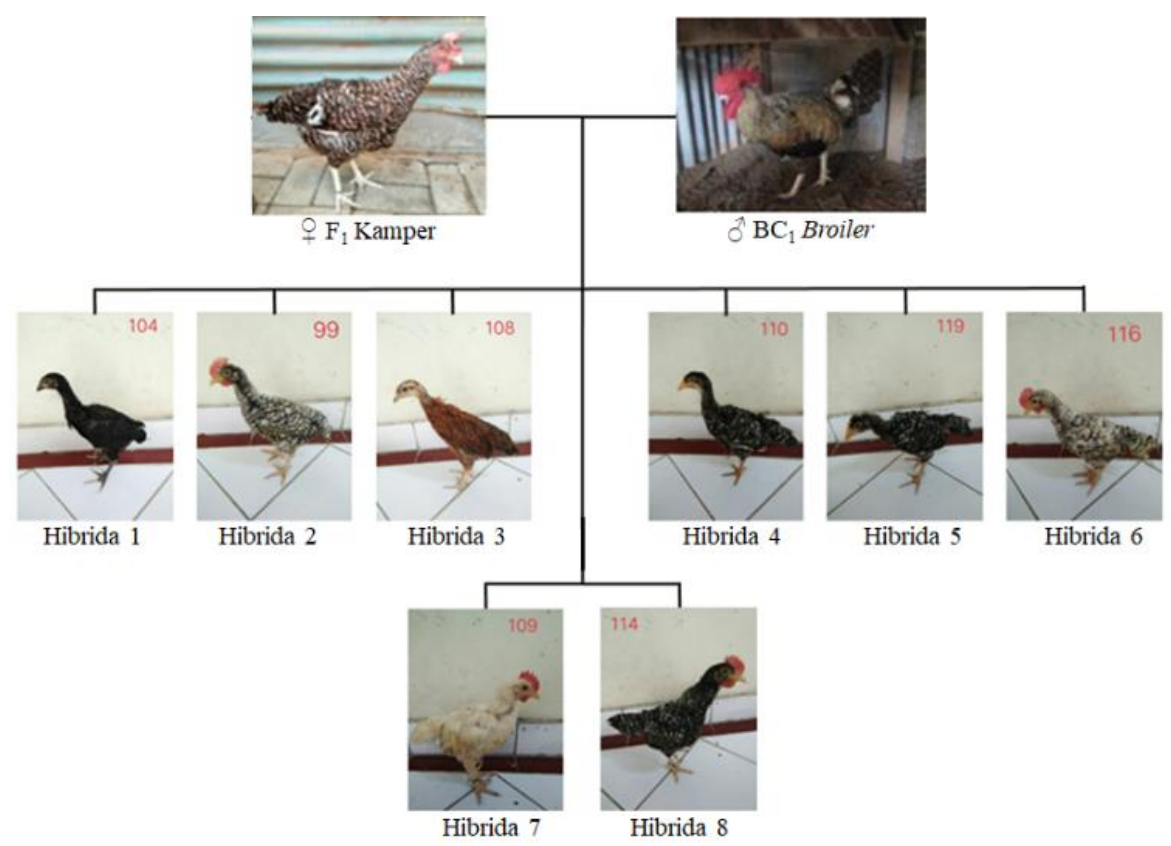

Figure 1. Breeding structure of Gama Ayam chicken

In Figure 2, average body weight of Gama Ayam chicken, Pelung chicken, $\mathrm{BC}_{1}$ Kambro chicken, $\mathrm{F}_{1}$ Kamper chicken and Broiler Cobb 500 indicates a significantly different performances during 49-days of period of rearing. Gama Ayam average body weight is 407.5 grams can be caused by genetic factors and maintenance settings that are less effective so that it affects the body weight. 


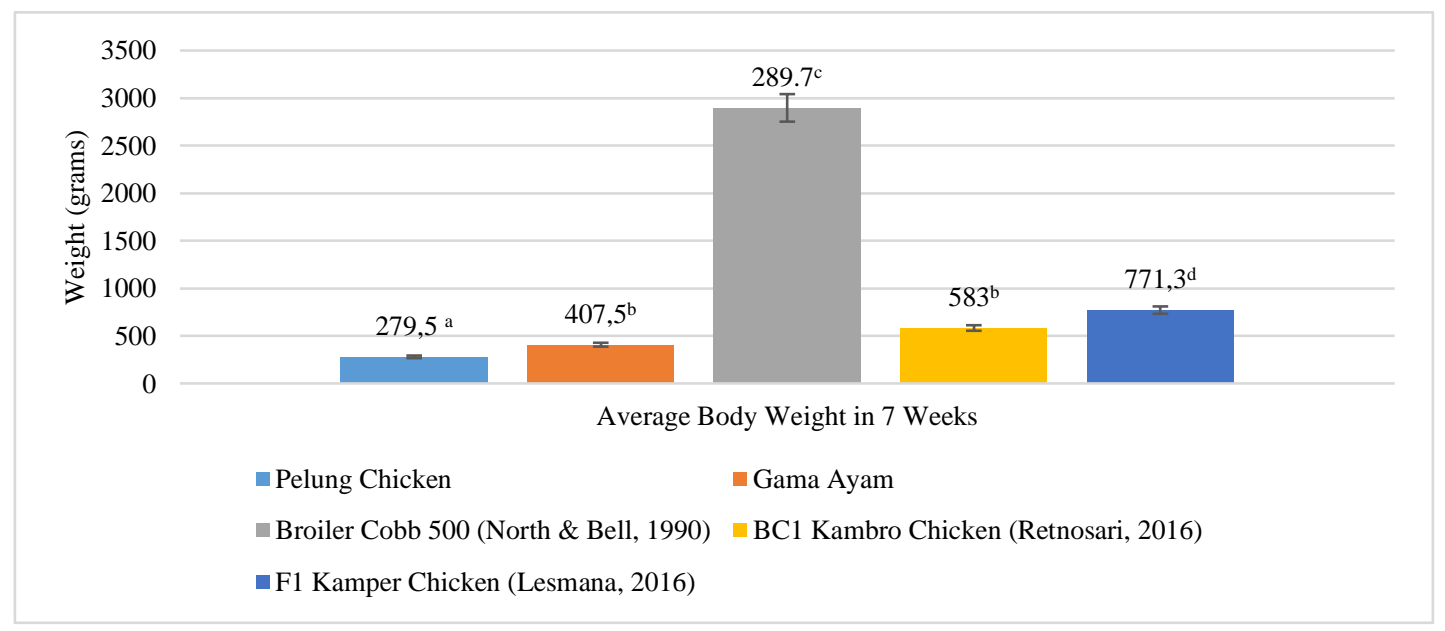

Figure 2. Body weight of Gama Ayam chicken, Pelung chicken, $\mathrm{BC}_{1}$ Kambro chicken, $\mathrm{F}_{1}$ Kamper chicken and Broiler Cobb 500 in 49-days rearing. The averages with different superscript differ significantly $(\mathrm{p}<0.05)$ based on Fisher's LSD post hoc

Gama Ayam showed a significantly higher body weight performance compare with Pelung and not differ with $\mathrm{BC}_{1}$ Kambro (Figure 2). In Figure 2, Gama Ayam reached 407.5 grams (gr) in 49-days of rearing and $F_{1}$ Kamper reached 771.3 grams (gr) in 49-days of rearing. This result can be explained with prior breeding structure of parental generation. Mahardhika \& Daryono (2019) found that Kambro body weight can reach $1244.14 \pm 453.82$ grams lower than Broiler Cobb 500 which can reach 1706.82 \pm 262.54 grams at 8 -weeks-old for the reason of only inherited $50 \%$ of Broiler Cobb 500 genetic components, whereas BT of $\mathrm{F}_{1}$ Pelung only reached $602,88 \pm 79,93$ grams with the same period. Backcross (BC) of Kambro with Pelung resulted in $\mathrm{BC}_{1}$ Kambro generation. The genetic components of Pelung then amplified and can be correlated with depression of body weight performance. Gama Ayam was produced with the aim to lower the fat deposition on carcass. Based on the body weight results the indication of LDL, cholesterol and triglyceride content on blood sample are hypothesized to be significantly lower in Gama Ayam chickens.

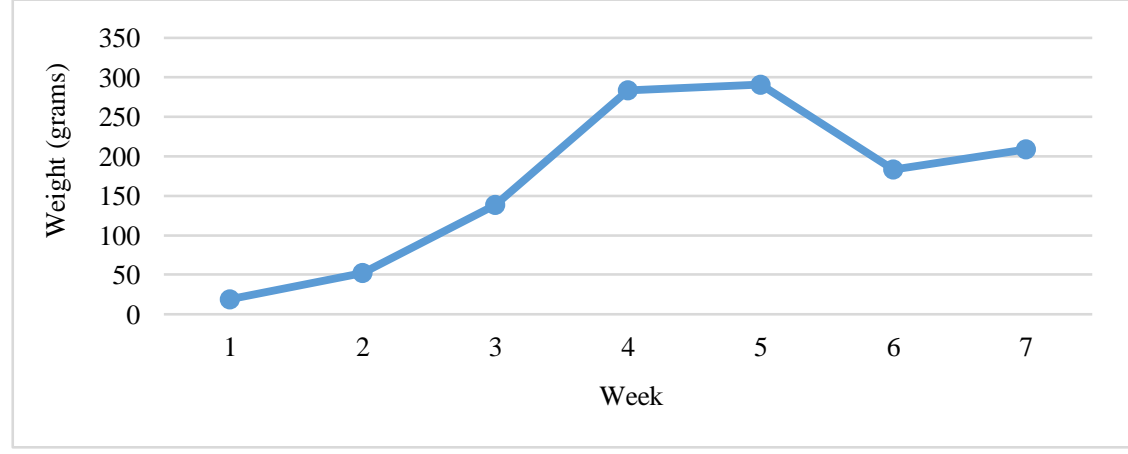

Figure 3. The average feed consumption of Gama Ayam population of 49-days rearing period

In Figure 3, the weight of feed spent by Gama Ayam during 49-days of observation shows an increase at the first week to the fifth week. Feed consumption in the fifth week reached 290.875 grams. A decrease in feed consumption can be observed during the sixth week and seventh week. A total feed consumption reached 9412 grams with an average feed consumption of each Gama Ayam chicken during 49-days of rearing period reached 1176.5 grams.

FCR value of Gama Ayam was 3.17 which implied to $3.17 \mathrm{~kg}$ of feed can produce $1 \mathrm{~kg}$ of meat. Fadilah \& Polana (2005) stated that FCR 
value of Pelung chicken is 3.35 and according to Maharatih et al. (2017) the FCR value of broiler chicken is among 1.52-1.88. The FCR value of Gama Ayam is between the FCR values of Pelung and broiler chicken. The FCR value of Gama Ayam was lower than Pelung which indicates a slightly better performance compare with Pelung chicken. Further research must be conducted with larger population size and sex classification in order to validate this findings.
Sequencing results indicates several SNP points in PPAR gene. PPAR gene SNPs polymorphism points found in the $172 \mathrm{bp}, 183$ bp, $297 \mathrm{bp}$, and $454 \mathrm{bp}$ nucleotide sequence. Several haplotypes were determined based on the points of the PPAR gene polymorphism related to blood lipid contents and body weight of Gama Ayam chicken. The types of mutations and haplotypes that were determined compared to blood lipid contents and body weight were presented in Table 2.

Table 2. Points of PPAR gene polymorphism of Gama Ayam, broiler, and Pelung chicken

\begin{tabular}{|c|c|c|c|c|c|c|c|c|c|c|}
\hline \multirow{3}{*}{$\begin{array}{c}\text { Sample } \\
\text { Name }\end{array}$} & \multicolumn{4}{|c|}{ PPAR gene polymorphisms } & \multirow{3}{*}{ Haplotype } & \multicolumn{4}{|c|}{ Blood Lipid Contents } & \multirow{3}{*}{$\begin{array}{l}\text { Weight } \\
\text { on } \\
\text { day } 49^{\text {th }} \\
\text { (gr) }\end{array}$} \\
\hline & \multicolumn{4}{|c|}{ Exon 2} & & \multirow{2}{*}{$\begin{array}{c}\text { Cholesterol } \\
\text { content } \\
(\mathrm{mg} / \mathrm{dl})\end{array}$} & \multirow{2}{*}{$\begin{array}{c}\text { LDL } \\
\text { content } \\
\text { (mg/dl) }\end{array}$} & \multirow{2}{*}{$\begin{array}{c}\text { HDL } \\
\text { content } \\
(\mathrm{mg} / \mathrm{dl})\end{array}$} & \multirow{2}{*}{$\begin{array}{c}\text { Triglyceride } \\
\text { content } \\
(\mathrm{mg} / \mathrm{dl})\end{array}$} & \\
\hline & $\begin{array}{c}\text { Sub } \\
\text { G172T }\end{array}$ & $\begin{array}{c}\text { Sub } \\
\text { A183G }\end{array}$ & $\begin{array}{c}\text { Sub } \\
\text { C297T }\end{array}$ & $\begin{array}{c}\text { Sub } \\
\text { T454A }\end{array}$ & & & & & & \\
\hline 16_I & $\mathrm{T}$ & $\mathrm{G}$ & $\mathrm{T}$ & $\mathrm{A}$ & $1 \mathrm{i}$ & 140.3 & 125.4 & 40.2 & 1073.3 & - \\
\hline 17_I & $\mathrm{T}$ & $\mathrm{G}$ & $\mathrm{T}$ & A & $1 \mathrm{i}$ & 150.3 & 104.1 & 31.2 & 242.3 & - \\
\hline 18_I & $\mathrm{K}$ & $\mathrm{R}$ & $\mathrm{T}$ & A & $2 \mathrm{i}$ & 95.4 & 53 & 30.6 & 136.2 & - \\
\hline 19_I & $\mathrm{T}$ & A & $\mathrm{Y}$ & A & $3 \mathrm{i}$ & 121.8 & 110.5 & 2.6 & 904.4 & - \\
\hline 20_I & $\mathrm{T}$ & $\mathrm{R}$ & $\mathrm{Y}$ & A & $4 \mathrm{i}$ & 86.6 & 49.6 & 29.1 & 81.6 & - \\
\hline $1 \_\mathrm{I}$ & $\mathrm{T}$ & $\mathrm{R}$ & $\mathrm{Y}$ & A & 1 & 107.4 & 41.3 & 47.9 & 17.5 & 398 \\
\hline 2_I & $\mathrm{T}$ & G & $\mathrm{T}$ & A & 2 & 93.5 & 39.2 & 40.6 & 19.7 & 424 \\
\hline 3_I & $\mathrm{T}$ & $\mathrm{R}$ & $\mathrm{Y}$ & A & 1 & 112.6 & 39.2 & 52.6 & 11.2 & 348 \\
\hline 4_I & $\mathrm{T}$ & $\mathrm{G}$ & $\mathrm{T}$ & A & 2 & 91.4 & 36.6 & 41.3 & 15.4 & 515 \\
\hline 5_I & $\mathrm{T}$ & $\mathrm{G}$ & $\mathrm{T}$ & A & 2 & 113.2 & 47.2 & 58.4 & 36.3 & 446 \\
\hline 6_I & $\mathrm{T}$ & $\mathrm{G}$ & $\mathrm{T}$ & A & 2 & 126.5 & 61 & 48.7 & 33.6 & 390 \\
\hline 7_I & $\mathrm{T}$ & $\mathrm{R}$ & $\mathrm{T}$ & A & 3 & 104.7 & 45.4 & 45.8 & 20.7 & 413 \\
\hline 8_I & $\mathrm{T}$ & A & $\mathrm{C}$ & A & 4 & 107.1 & 47.8 & 45 & 24.9 & 326 \\
\hline 9_I & $\mathrm{T}$ & $\mathrm{R}$ & $\mathrm{Y}$ & A & $1 b$ & 137.5 & 77.5 & 27 & 82.5 & - \\
\hline 10_I & $\mathrm{T}$ & A & $\mathrm{C}$ & A & $2 b$ & 104.8 & 52.6 & 15.1 & 50.9 & - \\
\hline 11_I & $\mathrm{T}$ & A & $\mathrm{C}$ & A & $2 b$ & 184.3 & 118.1 & 44 & 145.9 & - \\
\hline 12_I & $\mathrm{T}$ & $\mathrm{R}$ & $\mathrm{Y}$ & A & $1 b$ & 86.2 & 47.8 & 6.5 & 96.4 & - \\
\hline 13_I & $\mathrm{T}$ & $\mathrm{G}$ & $\mathrm{T}$ & $\mathrm{T}$ & $3 b$ & 121.1 & 65.7 & 40.6 & 62.9 & - \\
\hline 14_I & $\mathrm{T}$ & A & $\mathrm{C}$ & A & $2 b$ & 109.2 & 60.6 & 33.1 & 58.4 & - \\
\hline 15_I & $\mathrm{T}$ & $\mathrm{R}$ & $\mathrm{Y}$ & A & $1 b$ & 126.8 & 65.8 & 39 & 67.5 & - \\
\hline 21_I & $\mathrm{K}$ & $\mathrm{R}$ & $\mathrm{T}$ & A & $1 \mathrm{p}$ & 86 & 48.7 & 16.4 & 110.7 & - \\
\hline 22_I & $\mathrm{T}$ & A & $\mathrm{Y}$ & A & $2 p$ & 90.8 & 42.6 & 27.1 & 101.5 & - \\
\hline 23_I & $\mathrm{T}$ & $\mathrm{R}$ & $\mathrm{Y}$ & A & $3 p$ & 101.5 & 60.8 & 6 & 89.7 & - \\
\hline
\end{tabular}

In Table 3 the sample tag 16_I to 20_I refer to parentals, 1_I to 8_I refer to Gama Ayam, 9_I to 15_I refer to broiler chicken and 21_I to 23_I refer to Pelung chicken. Based on the table, it can be seen that there are 4 substitution points (G172T, A183G, C297T, and A454T) in exon 2 of PPAR gene. Amongst the four points of mutation, there is one point of polymorphism that was obtained by Meng et al. (2005) and Sun et al., (2013) specified as C297T nucleotide substitution. Sun et al., (2013) stated that there are mutations in native Chinese chickens with uncorrelated changes of amino acids to growth or fat deposition in chickens, these mutations called silent mutation. Silent mutation is a mutation that changes DNA but does not change the composition of the protein or amino acid that is coded (Chamary \& Hurst, 2009; Rosaiah et al., 2014; Zhang et al., 2012). Sun et al., (2013) also found several other polymorphism points including T5067908C and T5068303 which are related to LW (Live Weight), CW (Carcass Weight), EW (Eviscerated Weight), and ThW (Tight Muscle Weight) in chickens. One particular polymorphism point, C5068173T which is related to chicken carcass. Four points of polymorphism obtained formed four haplotypes in parentals, four haplotypes in Gama Ayam, three haplotypes in broiler chicken and three haplotypes in Pelung chicken. 
Han et al. (2011) reported that the analysis of the polymorphism association in the chicken PPAR gene, specified as (g-1784_-1768del16, c. $-1241 \mathrm{G}>\mathrm{A}$ and c. $-75 \mathrm{G}>\mathrm{A}$ ) is not only significantly associated with AFW and AFP (P $<0.05)$ but also significantly associated with LFW and LFP $(\mathrm{P}<0.05)$. PPAR gene mutations have also been reported to affect cardiovascular damage and death such as obesity, insulin resistance, and hypertension, this is because the PPAR gene regulates adipocyte differentiation and fat metabolism and is a molecular target of insulin sensitivity. Genetic variation in PPAR gene expression is also a potential contributor to the metabolic syndrome (Wu et al., 2006).

Zhou (2008) stated that abdominal fat accumulation in Chinese local chickens (yellow-haired broilers) decreases along with decreasing PPAR mRNA expression in abdominal adipose tissue. Royan et al., (2011) confirmed Zhou's (2008) findings by testing unsaturated fatty acids in the commercial strain of Ross 308 Broiler chicken strain, which was able to cause a significant reduction in abdominal fat percentage, due to a decrease in PPAR mRNA expression in abdominal adipose tissue.

Changes in amino acid composition due to polymorphism can be analyzed in relation to differences in chicken weight with Pearson correlation test. Haplotypes that have identical nucleotide bases with GeneBank references are considered to be normal phenotypes whereas haplotypes that have different nucleotide bases with GeneBank references are considered mutant phenotypes. The phenotype was tested for correlation at each point of polymorphism on blood lipid content and 49-days Gama Ayam body weight using Pearson correlation test. Pearson correlation test was only carried out on the polymorphism that occurred among hybrid chickens, specified as A183G substitution and C297T substitution. This analysis was performed to avoid data refraction of Pelung chicken, broiler chicken, $\mathrm{BC}_{1}$ Kambro, and $\mathrm{F}_{1}$ Kamper.

The results showed that PPAR gene polymorphism has no correlation with blood lipid content (cholesterol, LDL, HDL, and triglyceride). This can be caused by the possibility of PPAR gene polymorphism has significantly more effects on fat deposition in adipocyte region. In addition to the correlation test of blood lipid content, Pearson's correlation test was performed on the body weight of Gama Ayam at day $49^{\text {th }}$. The correlation test results of PPAR gene polymorphism on the body weight of 49-days-old Gama Ayam can be seen in Table 3.

Table 3. Results of PPAR gene polymorphism correlation test on the body weight of 49-days-old Gama Ayam

\begin{tabular}{|c|c|c|c|c|c|}
\hline \multirow{2}{*}{$\begin{array}{c}\text { Polymorphism } \\
\text { Genotype }\end{array}$} & \multicolumn{3}{|c|}{ Substitution A183G } & \multicolumn{2}{|c|}{ Substitution C297T } \\
\hline & AA & $\mathrm{AG}$ & GG & $\mathrm{CC}$ & $\mathrm{TT}$ \\
\hline Average Boyd Weight (gram) & 326 & 386.33 & 443.75 & 326 & 437.6 \\
\hline Correlation Coefficient (r) & \multicolumn{3}{|c|}{0.744} & \multicolumn{2}{|c|}{0.750} \\
\hline Signification & \multicolumn{3}{|c|}{$\begin{array}{c}0.034 \\
(\mathrm{P}<0.05)\end{array}$} & \multicolumn{2}{|c|}{$\begin{array}{c}0.032 \\
(\mathrm{P}<0.05)\end{array}$} \\
\hline Conclusion & \multicolumn{3}{|c|}{$\begin{array}{c}\text { Significantly very strong positive } \\
\text { correlation }\end{array}$} & \multicolumn{2}{|c|}{$\begin{array}{c}\text { Significantly very strong positive } \\
\text { correlation }\end{array}$} \\
\hline
\end{tabular}

Based on Table 4, PPAR gene polymorphism in Gama Ayam has a significantly strong positive correlation with body weight 49-days-old Gama Ayam. The Adenine substitution mutations to Guanine in nucleotides 183 and 297 PPAR gene correlates with the increase of body weight of Gama Ayam. Takada \& Kobayashi (2013) found a similar findings that polymorphism in PPAR gene is correlated with body weight of chickens and the increase of body mass index in chickens.

Mutations that occur in hybrid chickens affect changes in weight and chicken fat, this is consistent with the theory which states that the PPAR $\gamma$ gene is reported as a candidate gene that influences the growth and character of fat in chickens due to its large role in muscle fiber specialization and adipogenesis (Wu et al., 2006). 
Based on blood lipid content analysis, the average cholesterol level, average LDL level, average HDL level, and the average triglyceride levels in Gama Ayam chicken, broiler chicken and Pelung chicken were presented in Figure 4.

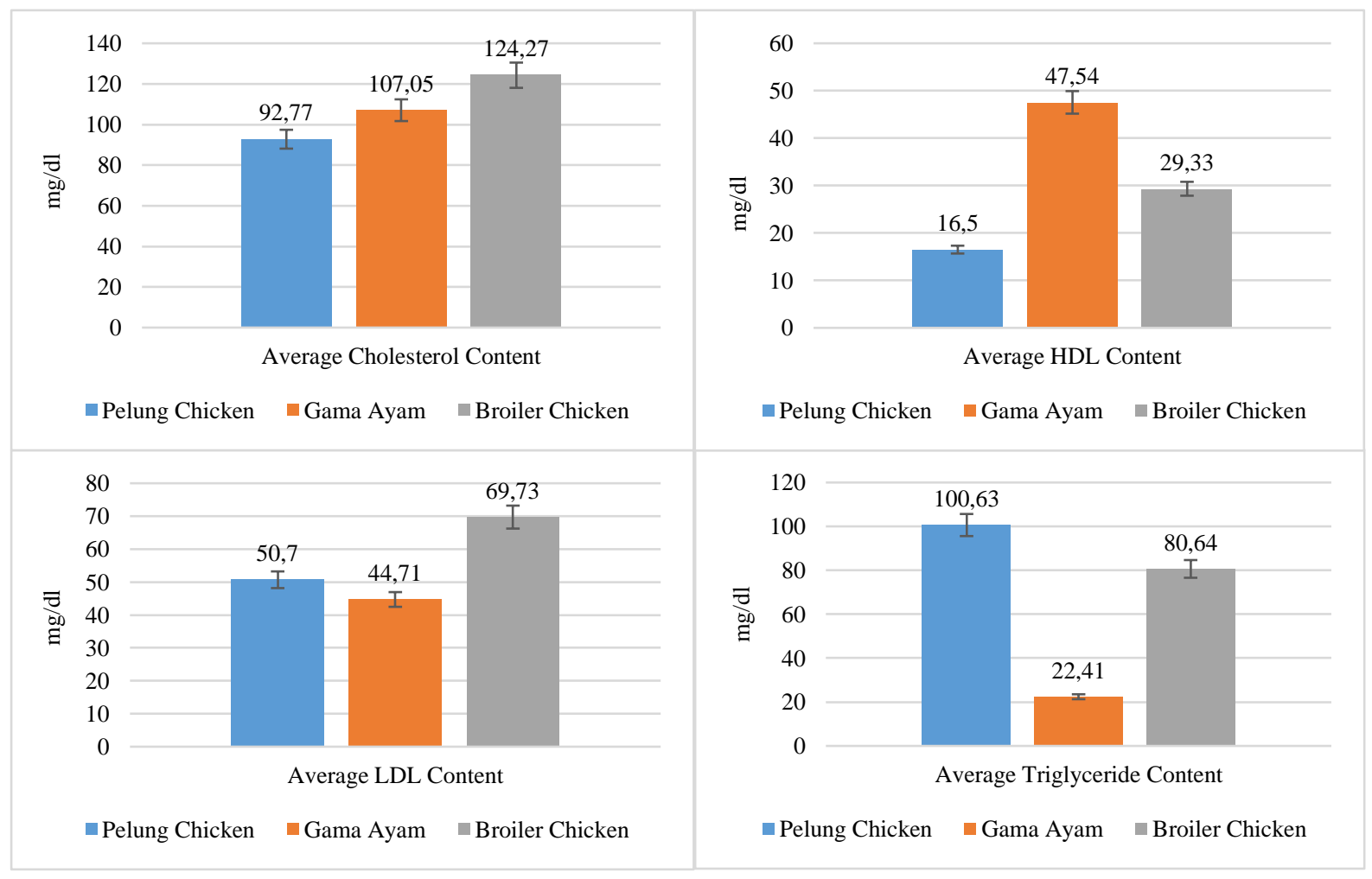

Figure 4. Comparison of blood lipid content

Based on Figure 4, triglyceride level, cholesterol level and LDL level in Gama Ayam were lower than broiler chicken. Sulistyoningsih et al. (2014) stated that lower cholesterol levels will reduce abdominal fat levels so that the carcass gets bigger. Low LDL levels indicate that the cholesterol level in the individual is also low. Gama Ayam chicken shows a higher HDL levels compared to Pelung chicken and broiler chicken. Harini \& Astirin (2009) stated that high HDL levels prevent the risk of atherosclerosis by transporting cholesterol from the peripheral tissues to the liver and reducing excessive cholesterol. Triglyceride levels in Gama Ayam placed in the lowest position compared to Pelung chicken and broiler chicken, low triglyceride levels will reduce cholesterol levels in the blood. Based on the description above, it can be assumed that hybrid chickens shows a prominent prospects to be used as parental generation in further selective breeding process.

\section{CONCLUSION}

Gama Ayam (407.5 grams/49-days-old) has significantly higher body weight compare to Pelung chicken and significantly lower body weight than broiler chicken. Gama Ayam has a FCR value of 3.17. Four points of PPAR gene polymorphism (G172T, A183G, C297T, and A454T) which produced 14 haplotypes of four haplotypes in hens, four haplotypes in Gama Ayam, three haplotypes in broiler chickens and three haplotypes in Pelung chicken. PPAR gene polymorphisms is not correlated with blood lipid content in Gama Ayam. A significantly strong correlation between PPAR gene polymorphism on the body weight of Gama Ayam at 49-days-old. Triglyceride level, cholesterol level and LDL level in Gama Ayam were lower than broiler chicken.

\section{ACKNOWLEDGMENTS}

The authors acknowledged the asisstance of Gama Ayam Research Team, Faculty of Biology, Universitas Gadjah Mada and Pusat Inovasi AgroTeknologi (PIAT) UGM 
throughout this research. This research was funded by Applied Research DIKTI 2019 (Penelitian Terapan: No.2830/UNI.DITLIT/DIT-LIT/LT/2019).

\section{REFERENCES}

Chamary JV, and Hurst LD. 2009. The price of silent mutations. Scientific American. vol 300(6): 46-53.

Colmenero FJ. 2000. Relevant factors in strategies for fat reduction in meat products. Trends in Food Science \& Technology. vol 11(2): 56-66. doi: https://doi.org/10.1016/S09242244(00)00042-X.

Direktorat Jenderal Peternakan dan Kesehatan Hewan. 2018. Statistik Peternakan dan Kesehatan Hewan 2018. Jakarta: Kementerian Pertanian Direktorat Jenderal Peternakan dan Kesehatan Hewan. http://ditjenpkh.pertanian.go.id.

Fadilah R, and Polana A. 2005. Panduan mengelola peternakan ayam broiler komersial. Jakarta: PT. Agromedia Pustaka. p 81.

Ferrini G, Manzanilla EG, Menoyo D, EsteveGarcia E, Baucells MD, Barroeta AC. 2010. Effects of dietary n-3 fatty acids in fat metabolism and thyroid hormone levels when compared to dietary saturated fatty acids in chickens. Livestock Science. vol 131(2-3): 287-291. doi: https://doi.org/10.1016/j.livsci.2010.03.01 7.

Gesta S, Tseng YH, Kahn CR. 2007. Developmental origin of fat: tracking obesity to its source. Cell. vol 131(2): 242256.

doi: https://doi.org/10.1016/j.cell.2007.10.004.

Han Q, Wang SZ, Hiu G, Li H. 2011. Haplotypes at the 5'-Flanking Region of Peroxisome Proliferator-Activated Receptor $\gamma$ Gene and Their Association with the Growth and Body Composition Traits in Chickens. Agricultural Sciences in China. vol 10(2): 296-303. doi: https://doi.org/10.1016/S16712927(11)60007-2.

Harini M, and Astirin OP. 2009. Kadar kolesterol darah tikus putih (Rattus norvegicus) hiperkolesterolemik setelah perlakuan VCO. Bioteknologi Biotechnological Studies. vol 6(2): 53-58. doi:

https://doi.org/10.13057/biotek/c060204.

Hattori H, Sato M, Masuoka K, Ishihara M, Kikuchi T, Matsui, T, Takase B, Ishizuka T, Kikuchi M, Fujikawa K, Ishihara M. 2004. Osteogenic potential of human adipose tissue-derived stromal cells as an alternative stem cell source. Cells Tissues Organs. vol 178(1): 2-12. doi: https://doi.org/10.1159/000081088.

Henuk YL, and Bakti D. 2016. Husbandry systems of keeping native chickens in tropical areas of Indonesia. Proceeding of $1^{\text {st }}$ International Conference on Tropical Animal Science and Production. July 2629. Thailand: Suranaree University of Technology. ISBN 978-974-533-710-7. pp. 147-150.

Liang MJ, Wang ZP, Xu L, Leng L, Wang SZ, Luan P, Cao ZP, Li YM, Li H. 2015. Estimating the genetic parameters for liver fat traits in broiler lines divergently selected for abdominal fat. Genetics \& Molecular Research. vol 14(3): 9646$9654 . \quad$ doi: https://doi.org/10.4238/2015.August.14.27

Lu Q, Wen J, Zhang H. 2007. Effect of chronic heat exposure on fat deposition and meat quality in two genetic types of chicken. Poultry science. vol 86(6): 1059-1064. doi: https://doi.org/10.1093/ps/86.6.1059.

Maharatih NMD, Sukanata IW, Astawa IPA. 2017. Analisis performance usaha ternak ayam broiler pada model kemitraan dengan sistem open house (studi kasus di Desa Baluk Kecamatan Negara). Peternakan Tropika. vol 5(2): 407-416.

Mahardhika IWS, and Daryono BS. 2019. Phenotypic performance of kambro crossbreeds of female broiler cobb 500 and male pelung blirik hitam. Buletin Veteriner Udayana. vol 11(2): 188-202. doi: https://doi.org/10.24843/bulvet.2019.v11.i 02.p12.

Meng H, Li H, Zhao JG, Gu ZL. 2005. Differential expression of peroxisome 
proliferator-activated receptors alpha and gamma gene in various chicken tissues. Domestic Animal Endocrinology. vol 28(1): 105-110. doi: https://doi.org/10.1016/j.domaniend.2004. 05.003 .

Parker, R. 2012. Aqualculture science. 3rd edition. New York: Cengage Learning. p. 281.

Peng Z, Mao X, Zhang J, Du G, Chen J. 2019. Effective biodegradation of chicken feather waste by co-cultivation of keratinase producing strains. Microbial cell factories. vol 18(84): 1-11. doi: https://doi.org/10.1186/s12934-019-11349.

Popkin BM. 2001. The nutrition transition and obesity in the developing world. The Journal of nutrition. vol 131(3): 871S873S.

doi: https://doi.org/10.1093/jn/131.3.871S.

Rosaiah K, Kumar PR, Singh KR, Satish SPS. 2014. Identification of citrullinaemia carrier and detection of a new silent mutation at 240bp position in ASS1 gene of normal Holstein cattle. Genetika. vol 46(2): 515-520. doi: https://doi.org/10.2298/GENSR1402515K

Royan M, Meng GY, Othman F, Sazili AQ, Navidshad B. 2011. Effect of conjugated linoleic acid, fish oil, and soybean oil on PPARs $(\alpha$ and $\gamma)$ mPNA expression in broiler chickens and their relation to bady fat deposits. International Journal of Molecular Science. vol 12(12): 85818595.

doi: https://doi.org/10.3390/ijms12128581.

Sartika RAD. 2008. Pengaruh asam lemak jenuh, tidak jenuh dan asam lemak trans terhadap kesehatan. Kesmas: National Public Health Journal. vol 2(4): 154-160. doi:

http://dx.doi.org/10.21109/kesmas.v2i4.25 8.

Sulistyoningsih M, Dzakiy MA, Nurwahyunani A. 2014. Optimalisasi feed additive herbal terhadap bobot badan, lemak abdominal, dan glukosa darah ayam broiler. Bioma: Jurnal Ilmiah Biologi. vol 3(2): 1-16. doi: http://dx.doi.org/10.26877/bioma.v3i2,\%2 0Oktober.639.

Sun Y, Liu R, Lu X, Hu Y, Zhao G, Zheng M, Chen J, Wang H, Wen J. 2013. Associations of polymorphisms in four candidate genes with carcass and/or meatquality traits in two meat-type chicken lines. Animal biotechnology. vol 24(1): 5365. doi: https://doi.org/10.1080/10495398.2012.74 2909.

Takada I, and Kobayashi M. 2013. Structural Featutes and Transcriptional Activity of Chicken PPARs $(\alpha, \beta$, and $\gamma)$. PPAR Research. vol 2013: 1-7. doi: https://doi.org/10.1155/2013/186312.

Tůmová E, and Teimouri A. 2010. Fat deposition in the broiler chicken: a review. Scientia Agriculturae Bohemica. vol 41(2): 121-128.

Wang G, Kim WK, Cline MA, Gilbert ER. 2017. Factors affecting adipose tissue development in chickens: A review. Poultry science. vol 96(10): 3687-3699. doi: https://doi.org/10.3382/ps/pex184.

Wang Y, Mu Y, Li H, Ding N, Wang Q, Wang Y, Wang S, Wang, N. 2008. Peroxisome proliferator-activated receptor- $\gamma$ gene: a key regulator of adipocyte differentiation in chickens. Poultry Science. vol 87(2): 226-232.

doi: https://doi.org/10.3382/ps.2007-00329.

Wu GQ, Deng XM, Li JY, Li N, Yang N. 2006. A potential molecular marker for selection against abdominal fatness in chickens. Poultry Science. vol 85(11): 1896-1899. doi: https://doi.org/10.1093/ps/85.11.1896.

$\mathrm{Wu}$ YJ, Wright JT, Young CR, Cartwright AL. 2000. Inhibition of chicken adipocyte differentiation by in vitro exposure to monoclonal antibodies against embryonic chicken adipocyte plasma membranes. Poultry science. vol 79(6): 892-900. doi: http://dx.doi.org/10.1093/ps/79.6.892.

Xu ZR, Wang MQ, Mao HX, Zhan XA, Hu CH. 2003. Effects of L-carnitine on growth performance, carcass composition, and metabolism of lipids in male broilers. Poultry Science. vol 82(3): 408-413. doi: https://doi.org/10.1093/ps/82.3.408. 
Zhang Z, Miteva MA, Wang L, Alexov E. 2012. Analyzing effects of naturally occurring missense mutations. Functional Dynamics of Proteins. vol 2012: 1-15. doi: https://doi.org/10.1155/2012/805827.

Zhou J. 2008. Effect of dietary conjugated linoleic acid (CLA) on abdominal fat deposition in yellow-feather broiler chickens and its possible mechanism. Asian-Australasian Journal of Animal Sciences. vol 21(12): 1760-1765. doi: https://doi.org/10.5713/ajas.2008.80165. 